\title{
A conservation status index, as an auxiliary tool for the management of cave environments
}

\author{
Christiane Ramos Donato ${ }^{1 *}$, Adauto de Souza Ribeiro ${ }^{2}$, and Leandro de Sousa Souto ${ }^{2}$ \\ ${ }^{1}$ Programa de Pós-graduação em Desenvolvimento e Meio Ambiente, Universidade Federal de Sergipe, São Cristóvão, Sergipe, Brazil \\ ${ }^{2}$ Departamento de Ecologia, Universidade Federal de Sergipe, São Cristóvão, Sergipe, Brazil
}

\begin{abstract}
The conservation of the Speleological Heritage involves bioecological, geomorphological and anthropogenic studies, both from inside the caves and from the external environments that surround them. This study presents a method to rank caves according to their priority for conservation and restoration. Nine caves were evaluated: indicators related to the environmental impacts and the vulnerability status presented by those caves (intrinsic features) and the values scored in a 'Cave Conservation Index' (CCl) were established. We also used a rapid assessment protocol to measure cave vulnerability for prioritization of conservation/ restoration actions (RAP-cr) comparing natural cavities with the same lithology, due to "strictu sensu" peculiarities. Based on the protocols applied in caves of the municipality of Laranjeiras, Sergipe, Northeastern Brazil, we concluded that the present method attended to the needs for the classification of the caves into categories of conservation/restoration status, using little time and financial effort, through rapid diagnostics that facilitate the comparisons. In this perspective, the $\mathrm{CCl}$ can be used to indicate areas that should be protected and caves that should be prioritized to have initiated activities of conservation and restoration.
\end{abstract}

Keywords: Cave Conservation Index; rapid evaluation protocol; speleological patrimony; cave environments; environmental impact

Received 10 March 2014; Revised 21 May 2014; Accepted 30 June 2014

Citation: Donato C.R., Ribeiro A.S. and Souto L.S., 2014. A conservation status index, as an auxiliary tool for the management of cave environments. International Journal of Speleology, 43 (3), 315-322. Tampa, FL (USA) ISSN 0392-6672 http://dx.doi.org/10.5038/1827-806X.43.3.8

\section{INTRODUCTION}

The success for the conservation of cave environments is directly associated with an accurate diagnosis of their intrinsic characteristics and their risk or vulnerability situation. In Brazil, most studies that conduct environmental assessment of caves tend to only characterize them qualitatively and indicate possible consequences and ways of reparation (e.g. Lino, 2001; Ferreira \& Horta, 2001; Ferreira, 2002; Lobo et al., 2009; Ferreira, 2010). These studies present either rapid or ascertained assessments as methodologies, but are not liable for comparison regarding the indication of vulnerability, extinction risk or the relative degree of stability of a particular cave in relation to others with similar characteristics.

The pursuit of appropriate methodologies has been proposed by Bovet \& Ribas (1992) and recently by Hardt (2008), but these approaches still present difficulties with regard to the comparison of results from different localities. More recently, Gomes (2010) made use of new techniques to characterize vulnerable sites using map overlap and GIS data. However, this methodology is useful when assessing large areas, even those which were not personally visited. Its negatives are the lack of qualified professionals to use these new technologies and the time spent preparing the maps and the possible absence of pre-existing data generating a margin of inaccuracy.

The use of an index to prioritize conservation of Brazilian karst systems began with the creation of the 'Importance Value for Cave Conservation' (Borges et al., 2012). This index is composed by indicators and statistics in order to rank the caves but this approach is limited, because they attribute to all the caves the same weight and importance, which would not be the most appropriate.

Such studies present the caves concerning its impacts or characteristics, but require long-term studies. To assist the regional management of caves with same lithology, this study proposes the use of the 'Cave Conservation Index' (CCI), which 
analyses the environmental impacts, pressures and vulnerability of intrinsic characteristics presented by caves. The function of the CCI is to classify the caves into categories to provide quick diagnosis, thus facilitating comparisons, and indicating priority areas to be protected.

The need of development and application of an practical and rapid index that could be more appropriated to Brazilian caves is evident (Donato, 2011), thereby the aim of this study is to present a methodology for a new CCI, for which were defined criteria regarding the geological, geomorphological, biotic, archaeological, paleontological, hydrological and environmental impact aspects for the evaluation of a pilot area, a set of nine caves found in the municipality of Laranjeiras, in Sergipe State, Brazil.

\section{METHODS}

\section{Study area}

The 'Cave Conservation Index' was developed to evaluate nine caves located in the microregion of the Cotinguiba, in the County of Laranjeiras (Fig. 1) (Correia, 2004). The rainy season is concentrated from May to August, and the driest months range from September to February. The average rainfall is $1300 \mathrm{~mm}$ per year, comprising the megathermal dry and sub-humid climate (Bomfim et al., 2002).

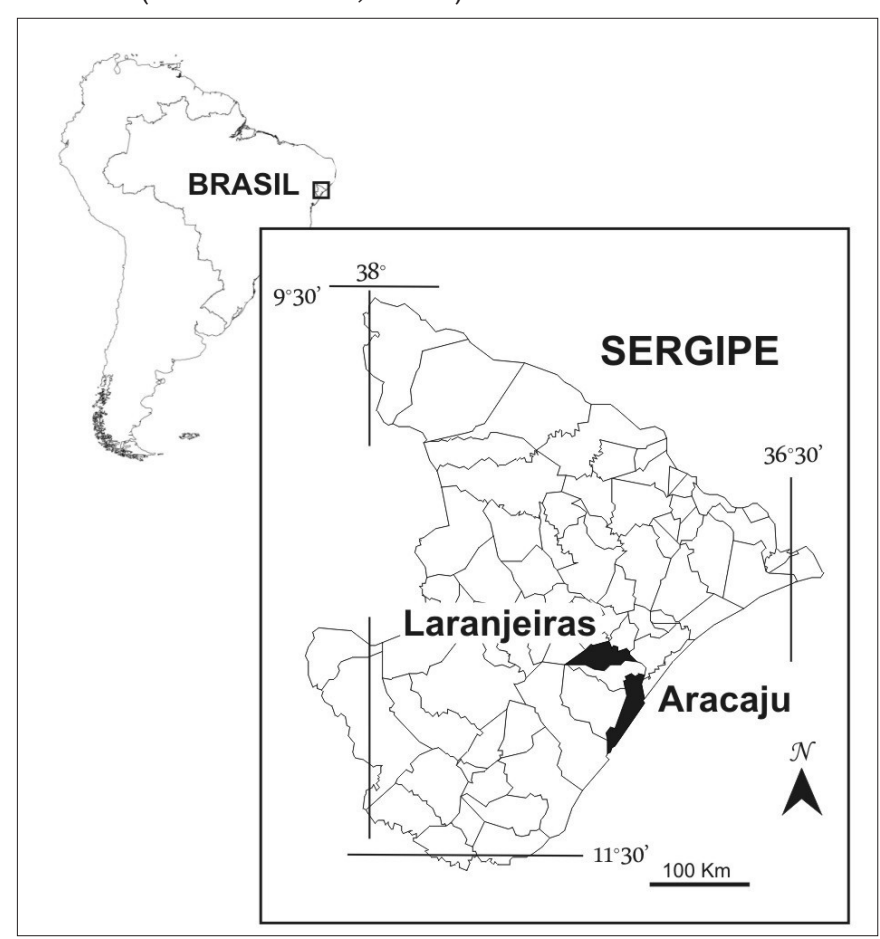

Fig. 1. Map of municipality of Laranjeiras, Sergipe, Northeastern Brazil. Source: Dantas et al. (2009).

The municipality is situated in the Rio Sergipe basin, represented mainly by the Cotinguiba and Buri rivers. Regarding the geomorphology, the study area is composed by river surfaces and remnants of coastal plain and coastal tablelands. Geologically, the County is in the Sedimentary Basin Sergipe/ Alagoas, which is divided into two sections: Cotiguiba and Riachuelo. The Cotinguiba section (Cenomanian to Coniacian of Upper Cretaceous) consists of argillaceous limestone with stratified layers. The Riachuelo section has regions with clay sediments interspersed with micaceous rock in medium and thin layers. Another region comprises a sequence of microcrystalline and pisolitic limestone (Araujo \& Santos, 2013). The soils are classified according to both the new Brazilian soil classification (Jacomine, 2009) and the old classification (Correia, 2004), indicating the predominance of Argisoil (red and yellow Podzolic and the variation of reddish Brunizem), while the Organosoil (indiscriminate halomorphics) originated from the mangrove. The soil formation process presents major bands of limestone, that naturally favors the presence of caves and the deployment of cement and lime industries in the region, which cause environmental problems.

As the index of Caves Conservation should be applied in caves in the same region, we chose the nine caves of this municipality because they are in an area with massive opencast mines, Thus at greater risk of destruction. The set of caves from the municipality of Laranjeiras was chosen due to: (i) the assembly of the largest collection of nearby caves registered in the State of Sergipe (CECAV, 2013); (ii) the differences in the karst formation of its caves; (iii) Due to the formation of limestone caves in the municipality, these cavities suffer great pressure from mining, as well as threats and environmental impacts arising from these activities (Donato et al., 2012).

The proposed method was tested in nine caves: Aventureiros $\left(10^{\circ} 48^{\prime} 11.5^{\prime} \mathrm{S}\right.$ 37 $\left.10^{\circ} 49.3^{\prime} \mathrm{W}\right)$, Raposa (1048'51.6"S 37¹0'45.4'W), Matriana (1048'04.0"S $\left.37^{\circ} 10^{\prime} 46.8^{\prime \prime} \mathrm{W}\right) \quad$ Pseudomatriana $\quad\left(10^{\circ} 47^{\prime} 51.6^{\prime \prime} \mathrm{S}\right.$ 37¹0'55.7'W), Janela (1049'22.2”S 37¹0'28'W), Tramandaí $\left(10^{\circ} 49^{\prime} 03.5^{\prime} \mathrm{S} \quad 37^{\circ} 10^{\prime} 12.5^{\prime} \mathrm{W}\right)$, Orixás (1049'04.6”S 37¹0'25.5'W), Raposinha (1048'48.9”S $\left.37^{\circ} 10^{\prime} 27.8^{\prime \prime} \mathrm{W}\right)$ and Pedra Furada (1049'14.7'S $\left.37^{\circ} 10^{\prime} 40.2^{\prime \prime} \mathrm{W}\right)$ in the municipality of Laranjeiras, State of Sergipe, Brazil.

\section{Study methodology}

The developed method is divided into three stages: environmental impact and pressure analysis, through the rapid assessment protocol of cave environmental impact; vulnerability analysis of the cave, through the rapid assessment protocol for prioritization of conservation and/or restoration actions; and comparison of results. The rapid assessment protocols should be filled out using secondary data and/or field trips. The results, obtained in percentage, are compared in the last stage, in which the final value is classified into a specific category.

\section{Rapid assessment protocol of cave environmental impact (RAP-cei)}

The protocol was built based on the structural model "Pressure-State-Response" (PSR), developed by the Organization for Economic Co-operation and Development (OECD, 1993), removing the response indicator from the table and using it only on proposals of resolutions for pressures and changes in the environmental status.

The indicators are qualitative and quantitative, in order to improve comparisons of existing data 
from different environmental impact studies. The parameters that were used as indicators were adopted according to information obtained in previous environmental impact studies in Brazilian caves (e.g. Lino, 2001; Ferreira, 2010; Cavalcanti et al., 2012) and studies about the cave fauna (Souza-Silva, 2008). The categories of impact were formulated based on the methodology used by Carmo (2010).

Possible pressure activities causing impact were separated into: mining, agriculture, tourism, disorderly visitation, water damming, urbanization, scientific research and engineering work. A single cave may present impacts coming from one or many of the described activities (Table 1).

Table 1. Rapid assessment protocol of environmental impact related to caves (RAP-cei).

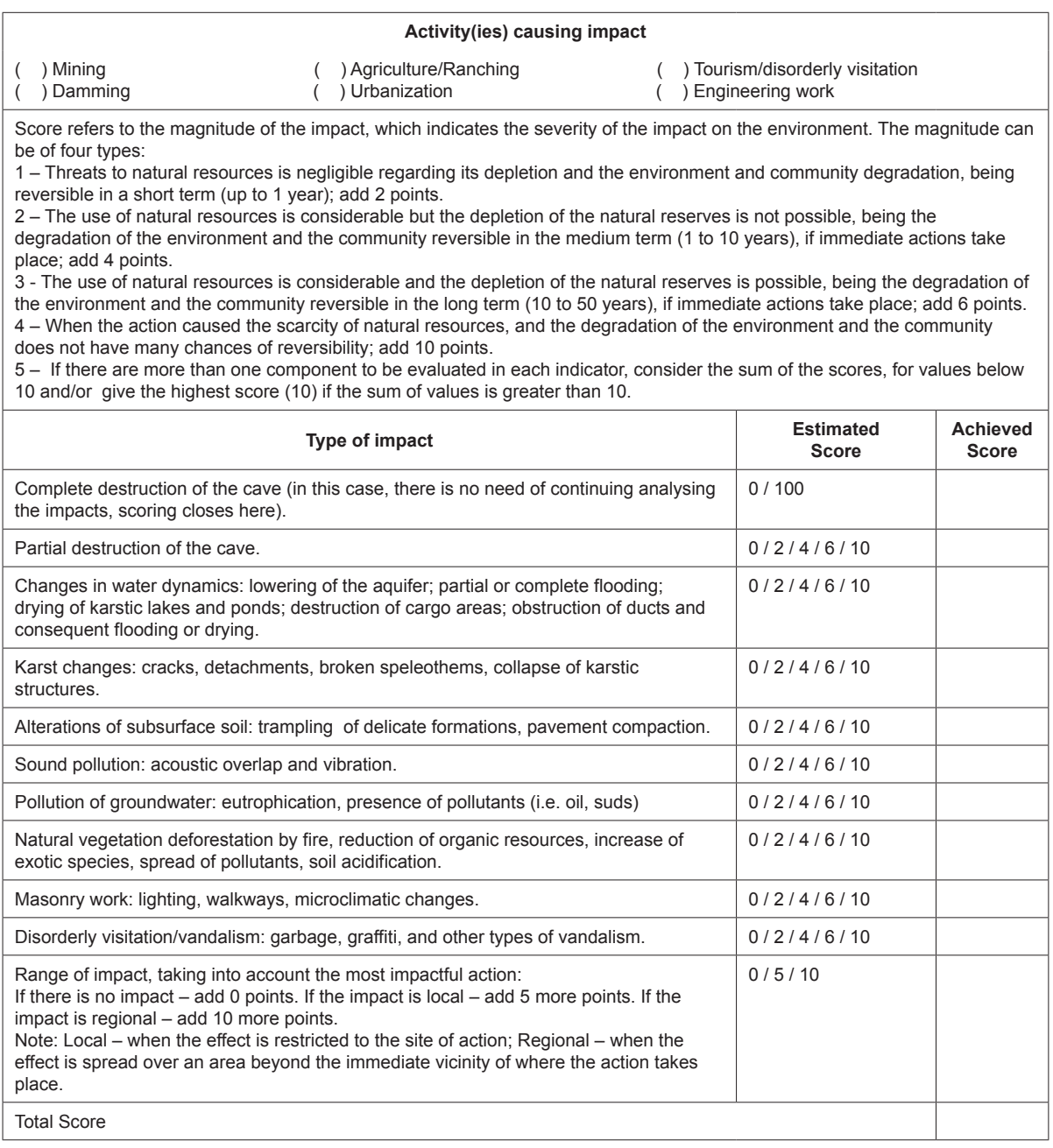

According to the cave's situation, it can be classified into six different categories concerning the presence of environmental impact:

a. Intact (I): natural communities, populations and ecological processes apparently intact, without anthropic alterations or threats. Score: $\leq 7$ points;

b. Stable (S): noticeable anthropic alterations possibly leading to local declines of natural populations. Integrity of the landscape maintained, ecological processes apparently intact. Score: 8 to 34 points;

c. Vulnerable (VU): outcrops with risk of extinction if adequate protection and management measures are not adopted. Loss and degradation of habitat. Score: 35 to 61 points;

d. Endangered (EN): outcrops with high extinction risk. Landscape alteration with habitat loss causing changes in the environment and ecological processes. Score: 62 to 84 points;

e. Critically Endangered (CR): outcrops with extremely high risk of extinction. Major changes in the surrounding landscape, or matrix, compromising the maintenance of native species and ecological processes. Score: 85 to 99 points;

f. Extinct (EX): cave that despite having been assessed in previous protocols do not exist anymore. Score: 100 points.

The final result is the value obtained in the RAP-cei protocol, which is already presented in percentage. In possession of the values, each cave can be compared with one another, the sorting and classification of the caves in ascending order, from the least to the most impacted, according to the total of points obtained for each natural cavity due to the observed impacts.

\section{Rapid assessment protocol of cave vulnerability for prioritization of conservation and/or restoration actions (RAP-cr)}

For the vulnerability analysis of the intrinsic characteristics of the caves, sixteen indicators were used, distributed among the internal and external environments, since both are interrelated, but have distinct characteristics. There are indicators with either more general and more specific features. The protocol has a quantitative assessment regarding the presence/absence of features at different levels.

The indicators from the internal (i) and external (e) environments are organized in three categories: biotic environment ( $\mathrm{BE}$; score $=3$ ), abiotic environment $(\mathrm{AbE}$; score $=2)$ and anthropic environment (AnE; score $=1$ ) (Table 2), which generate the Equation 01 of the RAP-cr, as follows:

$$
\begin{gathered}
\mathrm{RAP}-c r=\left\{\left[\left(\mathrm{BE}_{\mathrm{i}}+\mathrm{BE}_{\mathrm{e}}\right) \times 3\right]+\left[\left(\mathrm{AbE}_{\mathrm{i}}+\mathrm{AbE}_{\mathrm{e}}\right) \times 2\right]+\right. \\
\left.\left[\left(\mathrm{AnE}_{\mathrm{i}}+\mathrm{AnE}_{\mathrm{e}}\right) \times 1\right] / 60\right\} * 100 \\
\text { Equation } 01
\end{gathered}
$$

The values range from $0 \%$ to $100 \%$ and values equal to or smaller than $35 \%$ indicate low priority for conservation/restoration, values ranging from $36 \%$ to $75 \%$ suggest medium priority for conservation/restoration, and values from $76 \%$ onward explicit high priority for conservation/ restoration. For the case of scores between 35\% and $40 \%$ or between $75 \%$ and $80 \%$, small differences in assessment between two observers could occur. But this problem exists in established protocols (North et al., 2009; Van Beynen \& Bialkowska-Jelinska, 
Table 2. Rapid assessment protocol of cave status (RAP-cr).

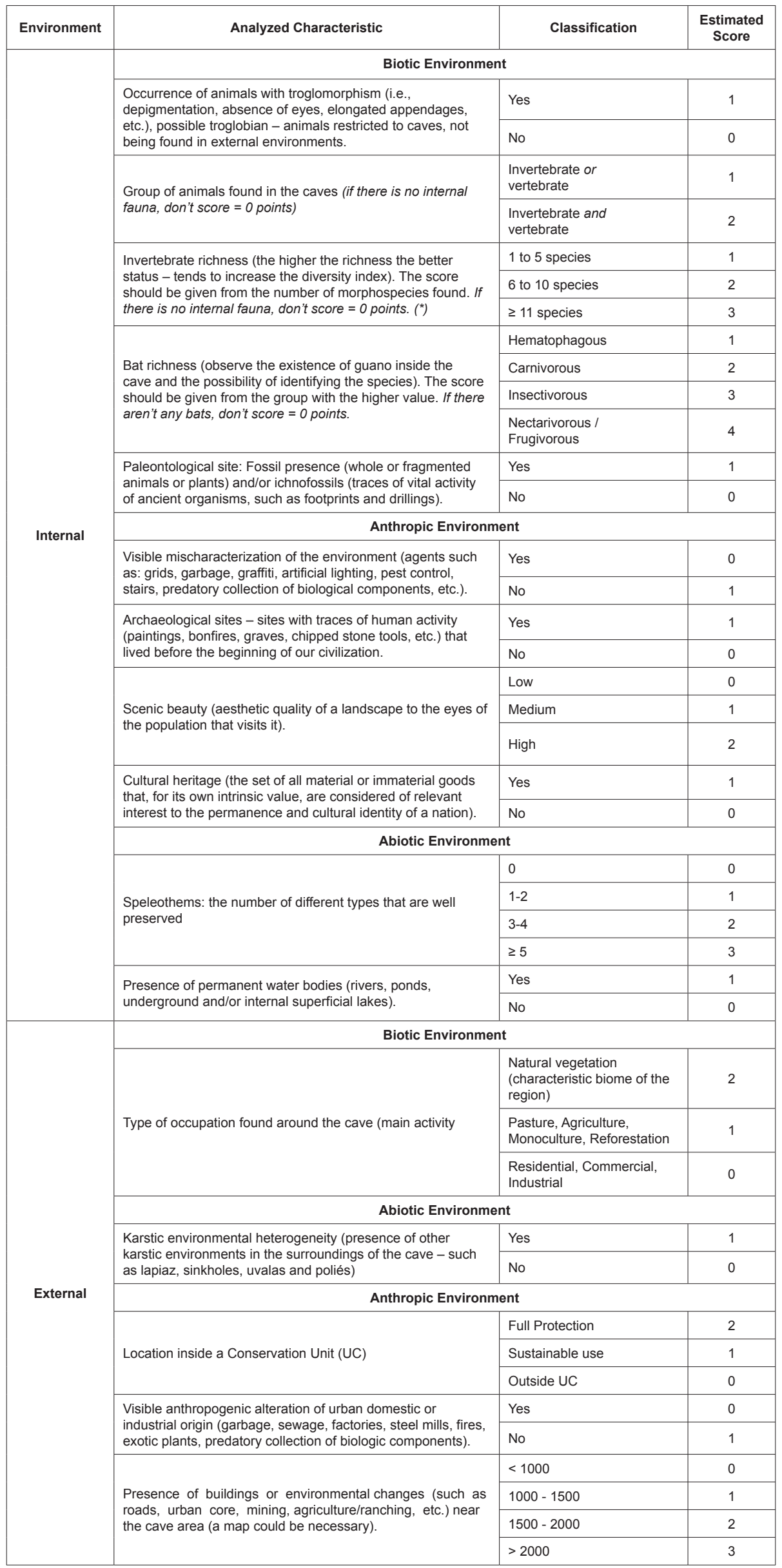

$\left({ }^{*}\right)$ - In case of karst regions with low richness of invertebrates, or in case of difficulty in separating the samples into morphospecies, the score can be obtained by the number of orders, using the same scoring criteria. 
2012). Thus, for cases where marginal values are found, we suggest the use of additional criteria that could be easy to visualize, to help in determining the most representative category. For example, one can observe whether among biotic, abiotic and anthropogenic characteristics evaluated are there any that stand out, such as high species richness of invertebrates, or speleothems as well as the presence of an important archaeological site. These features can only be observed in situ and can be an useful tool to deal with observed marginal values.

\section{Cave Conservation Index (CCI)}

To obtain the 'Cave Conservation Index' (CCI), the results of both rapid assessment protocols (RAP-cei and RAP-cr) were combined, as shown in Equation 02. The value of the vulnerability status of the cave (RAP-cr) is reduced from the environmental impact value (RAP-cel), giving a final value which classifies the caves into five classes of conservation priority (Table 3 ).

$$
\begin{aligned}
\mathrm{CCI}= & (\mathrm{RAP}-\mathrm{ce} i)-(\mathrm{RAP}-\mathrm{cr}) \\
& \text { Equation } 02
\end{aligned}
$$

Table 3. Cave classification according to the 'Cave Conservation Index' $(\mathrm{CCl})$, indicating priority for conservation and/or restoration actions.

\begin{tabular}{|c|c|}
\hline $\begin{array}{c}\text { Conservation } \\
\text { Index }\end{array}$ & $\begin{array}{c}\text { Cave } \\
\text { Classification } \\
\text { (Priority) }\end{array}$ \\
\hline $81-100 \%$ & Intense \\
\hline $61-80 \%$ & High \\
\hline $41-60 \%$ & Medium \\
\hline $21-40 \%$ & Moderated \\
\hline $0-20 \%$ & Low \\
\hline
\end{tabular}

\section{RESULTS}

In general, we found four pressure activities causing impacts: mining, agriculture, tourism/disorderly visitation and urbanization. However, not all of these impact-causing activities were witnessed at the same time in each cavities. The agriculture, urbanization and tourism/disorderly visitation caused impacts in all studied cavities. The mining had impacted Janela, Orixás and Pedra Furada.

These actions caused different types of impacts, with different intensity and range in each of the studied caves. The range of the impacts varied from local to regional. The results presented refer to field observations made from July 2010 to July 2011, thus some attributes may vary in values over time.

There were eight main types of impacts found: karst changes (cracks, detachment and broken speleothems); soil alterations (erosion, landfill, rubble, trampling of delicate formation sand pavement compaction); natural vegetation loss (deforestation, fire, reduction of organic resources, increase of exotic species and pollution); sound pollution (acoustic overlap and vibration); engineering works (mine steps); disorderly visitation/vandalism (trash, graffiti and microclimatic changes); and partial destruction of the cave (internal mining for removal of lime).

After using the RAP-cei, the caves were divided into two groups according to their respective scores:
Aventureiros (9\%), Matriana (21\%), Raposa (23\%), Pseudomatriana $(23 \%)$, Janela $(25 \%)$, Tramandai $(27 \%)$ and Orixás $(29 \%)$ are stable with regard to their environmental characteristics and faunal communities, while Raposinha (41\%) and Pedra Furada (55\%) are vulnerable (Table 4).

Table 4. Assessment of the environmental impacts, cave status, value of the 'Cave Conservation Index' $(\mathrm{CCl})$ and priority ranking for conservation/restoration actions in the caves from Laranjeiras/ Sergipe/Brazil.

\begin{tabular}{|c|c|c|c|c|c|c|}
\hline $\begin{array}{l}\text { Cave } \\
\text { Code }\end{array}$ & Richfau & Richveg & CEI & CS & CCI & CP \\
\hline CAV1 & 57 & 12 & S & Me & Me & 1 \\
\hline CAV2 & 79 & 14 & S & Me & Mo & 3 \\
\hline CAV3 & 78 & 4 & S & Me & Me & 2 \\
\hline CAV4 & 78 & 15 & S & Me & Mo & 5 \\
\hline CAV5 & 91 & 7 & S & Me & L & 8 \\
\hline CAV6 & 89 & 14 & S & Me & Mo & 4 \\
\hline CAV7 & 70 & 14 & S & Me & Mo & 6 \\
\hline CAV8 & 49 & 9 & VU & Me & L & 7 \\
\hline CAV9 & 141 & 15 & VU & Me & L & 9 \\
\hline
\end{tabular}

Notes: Aventureiros (CAV1), Janela (CAV 2), Raposa (CAV 3), Tramandaí (CAV 4), Matriana (CAV 5), Pseudomatriana (CAV 6), Orixás (CAV 7), Raposinha (CAV 8), Pedra Furada (CAV 9); Richness of the internal fauna (Richfau); Richness of the external flora (Richveg); Cave classification according to the environmental impact (CEI); Cave classification according to the intrinsic characteristics status (CS); Cave priority ranking for conservation/restoration actions (CP); Cave Conservation Index (CCl); Stable (S); Vulnerable (VU); Low (L); Moderated (Mo); Medium (Me).

The state of vulnerability analysis of the caves (RAP-cei) indicated that no troglomorphic species were found in the internal biotic environment (that is, possessing morphological characteristics of a troglobian species, such as depigmentation, absence of eyes, elongated appendages, etc.), but other specimens of vertebrates and invertebrates were successfully found. All the caves have specimens of frugivorous and nectarivorous bats, except for Matriana, which does not have a bat population. Only Raposa presents a paleontological site. The internal anthropic environment of all the caves presents some sort of visible mischaracterization, does not have archaeological sites and holds low or medium scenic beauty, although Matriana and Pedra Furada are considered cultural heritage sites. The internal abiotic environment of the caves does not present permanent water bodies, except for the Aventureiros. All the studied caves have some sort of speleothems.

The external biotic environment presents pasture, agriculture, monoculture or reforestation around all the caves. All studied caves don't have an external abiotic environment presenting environmental heterogeneity, except for the Matriana which is standing amid a field of lapiaz. The external anthropic environment of all caves states that they are not included in a conservation area, since there are visible anthropogenic alterations from domestic urban or industrial origins, besides the presence of buildings or major environmental modifications from, at most, fifteen hundred meters away from the entrance of the caves. 
Regarding the intrinsic characteristics related to the vulnerability status of the studied caves, all were classified as medium priority for conservation/ restoration, as follows: Raposa (70\%) and Aventureiros (65\%), Janela (60\%), Orixás (58\%), Raposinha (58\%), Pedra Furada (57\%), Tramandaí (57\%), Pseudomatriana (55\%) and Matriana (37\%) (Table 4).

The results obtained with the 'Cave Conservation Index' (CCI) classified the caves following their order of priority of conservation or restoration: Aventureiros (56\%), Raposa (47\%), Janela (35\%), Pseudomatriana (32\%), Tramandaí (30\%), Orixás (29\%), Raposinha (17\%), Matriana (16\%) and Pedra Furada (2\%). Therefore, the Aventureiros and Raposa have priority of conservation/restoration in relation to other caves (Tables 3 and 4).

\section{DISCUSSION}

After analysis of the protocols, it was observed that all studied natural cavities are under some extent of pressure and present environmental impacts affecting their internal environments, while also containing heterogeneous environmental conditions. These conditions mainly reflect the presence of a large population of bats (Janela, Raposa and Pseudomatriana) and the availability of microhabitats and trophic resources (presence of guano from hematophagous, frugivorous and insectivorous bats; fallen blocks; watercourses; roots; and litter in the various natural cavities). Previous studies have demonstrated the importance of considering the biota as a factor to increase the utilization of the disturbance indexes (van Beynen \& Townsend, 2005; van Beynen et al., 2007).

Given the pressures and impacts posed by these caves, we suggest the development of an environmental management plan at the municipality level, consisting of five programs for the conservation of the speleological collection of Laranjeiras, which should focus on: (i) surveillance and environmental monitoring to restrain impacts; (ii) environmental restoration and landscape recovery of sites where mining occurred and containment of fires and deforestation; (iii) environmental education with focus on the principles of local culture, conserving myths and legends about the caves which can help maintaining the original characteristics of the Atlantic forest; (iv) a specific plan for waste disposal in caves; (v) a plan to ensure resources for environmental compensation and land use planning.

For the restoration of the epigeal environment, it is necessary to implement the current legislation, which indicates a minimum perimeter of maintained native vegetation with a radius of 250 meters around each cave (Brazil, 2004). Furthermore, the agricultural and livestock in the area should be avoided or suspended, the non-native species should be gradually removed and the native vegetation should be restored using agroforestry or native species. All actions above mentioned will assist in the restoration of the surround environment and will help conserving the caves.
The creation of ecological corridors after restoration of the cave surroundings is possible, due to the proximity between them, thus enhancing the conservation of the influence areas of the caves (Marra, 2008). Encouraging the creation and implementation of Private Natural Heritage Reserves (RPPN), a model of environmental conservation in accordance with Brazilian legislation, in the area of caves with high hypogeal fauna richness and possessing natural or recovering vegetation is also a relevant option (Souza-Silva, 2008).

Caves considered as Cultural Heritage by the surrounding population can be listed as such, like the Pedra Furada and Matriana. The National Institute of Historic and Artistic Heritage (IPHAN) is the Brazilian institute responsible for registering a determined patrimony (environmental, cultural, historic or architectural) as a public heritage, intending to protect its physical integrity and safeguard its memory. This process does not turn the patrimony unavailable and its use is allowed if authorized and accompanied by personnel of the relevant government body. Therefore, tourism can still occur at these sites (Marra, 2008).

All the caves that have been impacted by human activities, including tourism, should have implemented recovery and management plans. To assist restoration of the karst environment, it is required intervention and management through the removal of garbage, cleaning of speleothems and painted walls (HildrethWerker \& Werker, 2006).

The proposed protocols for the classification of caves according to the experienced pressures and environmental impacts and for the prioritization of conservation/restoration actions also serve as parameters for the conservation of the associated fauna and flora. Through the use of the presented indicators, it is possible to identify the pressures causing the environmental impact in the caves, the effects and magnitude of these impacts, which cave should be restored and which should be preserved, and which of them should receive the conservation/ restoration actions first.

The ranking according to the vulnerability resulting from the impacts, and to the prioritization of actions can assist the decision making of which caves deserve more attention at first. However, it should be stressed that this study does not suggest that the remaining cavities should be put aside; it only indicates a general rank of action.

The presented protocol can also be used to indicate caves that must have management plans prepared more urgently, and which should not be suppressed while still having a high relevance inside an area with other high relevance caves that need rapid restoration of their attributes. Besides, the methodology presented in this study can be used to assist managers in making decisions about which caves can be used for tourism and recreation activities while others would be kept closed or used only in research or conservation. Furthermore, this protocol may be useful in studies of implementation of national parks and other protected areas in a given lithologic region, indicating the vulnerabilities and needs for conservation or restoration of karst ecosystems. 
This protocol was initially performed to be used by evaluators from karst regions in Atlantic Forest complex and other Tropical environments, due to the rapid urban development and the high degree of disturbance in these environments associated to the great importance of biota in the scoring. With regard to the application of this study elsewhere, it is worth mentioning the need to adapt the indicators in light of local circumstances. Other indicators that may seem obvious to other locations did not appear in the obtained results due to the characteristics of the studied area.

Through the refinement of the index, the aim is to increase its applicability to resource managers. Thus, before applying the protocol here presented to another region, certain factors must be considered. Part of that refinement encompass: 1) the use of aerial photographs to improve the accurance in the determination of environmental impacts in the vicinities of the caves rather than relying on topographic or Cap maps; 2) for temperate regions, the indicators of species richness of invertebrates and their abundance needs to be adapted; and 3) the broadening of the indicator descriptions (including scores) to encompass a greater diversity of possible scenarios.

This reformulation is crucial to adjust the utility of the protocol to the reality of the new study sites. However, we stress that when determining an indicator's score, the evaluator should not only rely on the indicator descriptor but also on the overall characterization of the score. Further research is also necessary, in this sense, to validate the identified criteria in other localities, as well as to expand this material to obtain a methodology that can be applied also in more varied environmental contexts.

\section{ACKNOWLEDGEMENTS}

We would like to thank the PRODEMA (Postgraduate Program in Development and Environment), program which awarded C. R. D. her master's degree. We are also extremely grateful for the financial support provided by the DAAD (Deutscher Akademischer Austauschdienst).

\section{REFERENCES}

Bomfim L.F.C., Costa, I.V.G. \& Benvenuti S.M.P., 2002 - Projeto Cadastro da Infra-Estrutura Hidrica do Nordeste: Estado de Sergipe. Diagnóstico do Município de Laranjeiras. Aracaju: CPRM, 25 p.

Borges P.A.V., Cardoso P., Amorim I.R., Pereira F., Constância J.P., Nunes J C., Barcelos P., Costa P., Gabriel R. \& Dapkevicius M.d.L., 2012 - Volcanic caves: priorities for conserving the Azorean endemic troglobiont species. International Journal of Speleology, 41 (1): 101-112.

http://dx.doi.org/10.5038/1827-806X.41.1.11

Bovet M.T. \& Ribas J., 1992 - Metodologia general de los estudios de paisaje. In: BOLLÓs, M. (Org.) Manual de Ciência Del Paisaje. Teoria, métodos y aplicaciones. Barcelona: Masson S.A.: 123-134.

Brazil 2004 - Resolução CONAMA no 347, de 10 de setembro de 2004. Dispõe sobre a proteção do patrimônio espeleológico. http://www.mma.gov.br/ port/conama/legiabre.cfm?codlegi $=452$
Carmo F.F., 2010 - Importância Ambiental e Estado de Conservação dos Ecossistemas de Cangas no Quadrilátero Ferrífero e Proposta de Áreas-Alvo para a Investigação e Proteção da Biodiversidade em Minas Gerais. Dissertation (Master's in Ecology, Conservation and Management of Wildlife). Universidade Federal de Minas Gerais, Belo Horizonte, 98 p.

http://www.icb.ufmg.br/pgecologia/dissertacoes/D240 flavio foneca do carmo.pdf

Cavalcanti L.F., Lima M.F., Medeiros R.C. S. \& Meguerditchian I. (Orgs), 2012 - Plano de ação nacional para a conservação do patrimônio espeleológico nas áreas cársticas da Bacia do Rio São Francisco. Brasília: Instituto Chico Mendes de Conservação da Biodiversidade, $140 \mathrm{p}$.

CECAV (Centro Nacional de Pesquisa e Conservação de Cavernas), 2013 - Base de dados geoespacializados das cavernas do Brasil: Sergipe. Brasília: CECAV. http://www.icmbio.gov.br/cecav/downloads/mapas.html

Correia C.O. (coord.), 2004 - Sergipe Atlas Digital Sobre Recursos Hidricos. Versão 1.1. Departamento de Administração e Controle de Recursos Hídricos, Coordenadoria de Informações sobre Recursos Hídricos. 1 CD-ROM.

Dantas M.A.T., Donato C.R.; Almeida E.A.B, Barreto E.A.S., Silva E.J., Soares R S., Barros-Neto H.M.C., Ferreira A.S., Souza S.S., Santana M.E.V. \& Oliveira D.M., 2009 - Inventário Espeleológico de Sergipe: As cavernas de Laranjeiras. Proceedings of the $30^{\circ}$ Congresso Brasileiro de Espeleologia. Belo Horizonte, Minas Gerais: 43-50. http://www.sbe.com.br/anais30cbe/30cbe 043-050.pdf

Donato C.R., 2011 - Análise de impacto sobre as cavernas e seu entorno no Municipio de Laranjeiras, Sergipe. Dissertation (Master's in Development and Environment). Universidade Federal de Sergipe, São Cristóvão, 198 p. http://bdtd.ufs.br/tde_busca/arquivo.php?codArquivo=1021

Donato C.R., Ribeiro A.S. \& Sousa-Souto L., 2012 - Análise ambiental e avaliação da relevância das cavernas do Municipio de Laranjeiras, Sergipe. EspeleoTema (São Paulo), 23 (2): 59-69. http://www.sbe.com. br/espeleo-tema/espeleo-tema v23 n2 059-069.pdf

Ferreira C.F., 2002 - Impactos Ambientais em Cavernas: estudo de caso das cavidades do Município de Lagoa da Prata - MG. Under graduate thesis (Undergraduate in Geography). Universidade Federal de Minas Gerais, Belo Horizonte, 137 p.

Ferreira C.F., 2011 - Análise de impactos ambientais em terrenos cársticos e cavernas. In: CECAV. III Curso de Espeleologia e Licenciamento Ambiental. Brasília: CECAV/Instituto Chico Mendes de Conservação da Biodiversidade: 123-148.

http://www.icmbio.gov.br/cecav/images/download/ Apostila\%20Curso $\% 20$ de $\% 20$ Espeleologia $\% 20 \mathrm{e} \% 20$ Licenciamento\%20Ambiental.pdf

Ferreira R.L. \& Horta L.C.S., 2001 - Natural and human impacts on invertebrate communities in brazilian caves. Revista Brasileira de Biologia, 61(1): 7-17. http://dx.doi.org/10.1590/S0034-71082001000100003

Gomes M., 2010 - Proposta metodológica para identificação de áreas vulneráveis para a conservação do patrimônio espeleológico brasileiro. Undergraduate thesis (Specialization in Geoprocessing). Universidade Federal de Minas Gerais, Belo Horizonte, 62 p. http://www.csr.ufmg.br/ geoprocessamento/publicacoes/MAURO.pdf

Hardt R., 2008 - Sistema cárstico e impactos antrópicos: considerações sobre o manejo. Proceedings of the $1^{\circ}$ Simpósio de Pós-graduação em Geografia do estado de São Paulo - SIMPGEO/SP e VIII Seminário de Pósgraduação em Geografia da Unesp. Rio Claro, São Paulo: 1295-1309. 
Hildreth-Werker V. \& Werker J.C., 2006 - Cave conservation and restauration. Alabama, USA: National Speleological Society, 600 p.

Jacomine P.K.T., 2008-2009 - A nova classificação brasileira de solos. Anais da Academia Pernambucana de Ciência Agronômica, Recife, 5-6: 161-179.

Lino C.F., 2001 - Cavernas: o fascinante Brasil subterrâneo. São Paulo: Gaia, 288 p.

Lobo H.A.S., Piloneto A., Benites G., Rangel M.C R., Silva M.C.F., Melo M.E. \& Ferreira R.P., 2006 - Reflexões e Propostas Para as Politicas Públicas de Espeleoturismo no Brasil. Revista Global Tourism, 2 (1): 01-17.

Marra R.J.C., 2008 - Critérios de relevância para classificação de cavernas no Brasil. Thesis (PhD in Sustainable Development). Universidade de Brasília, Brasilia, 393 p.

North L.A., van Beynen P.E. \& Parise M., 2009 Interregional comparison of karst disturbance: Westcentral Florida and southeast Italy. Journal of Environmental Management. 90:1770-1781. http://dx.doi.org/10.1016/j.jenvman.2008.11.018

OECD (Organisation for Economic Co-operation and Development), 1993 - Core set of indicators for environmental performance reviews: a synthesis report by the Group on the State of the Environment. Environmental Monographes, Paris, 83, 39 p.
Santos W.A. \& Araújo H.M., 2013 - Geologia e recursos hidricos superficiais e subterrâneos da sub-bacia hidrográfica do rio Cotinguiba-SE. Boletim de Geografia, 31 (3): 5-18. http://dx.doi.org/10.4025/bolgeogr.v31i3.17537

Souza-Silva M., 2008 - Ecologia e conservação das comunidades de invertebrados cavernícolas na Mata Atlântica Brasileira. Thesis (PhD in Ecology, Conservation and Management of Wildlife). Universidade Federal de Minas Gerais, Belo Horizonte, 224 p.

van Beynen P.E., Feliciano N., North L. \& Townsend K.M., 2007 - Application of a karst disturbance index in Hillsborough County, Florida. Environmental Management, 39: 261-277. http://dx.doi.org/10.1007/s00267-005-0393-x

van Beynen P.E. \& Townsend K.M., 2005 - A disturbance indexfor karst environments. Environmental Management, 36 (1): 101-116.

http://dx.doi.org/10.1007/s00267-004-0265-9

van Beynen P.E. \& Bialkowska-Jelinska E., 2012 Human disturbance of the Waitomo catchment, New Zealand. Journal of Environmental Management, 108: 130-140.

http://dx.doi.org/10.1016/j.jenvman.2012.04.038 